\title{
SISTEM APLIKASI PEMBELAJARAN BANGUN RUANG UNTUK SEKOLAH DASAR
}

\author{
Sudewi, Rita Irviani, Trisnawati \\ STMIK Pringsewu Lampung \\ J1. Wisma Rini No. 09 pringsewu Lampung \\ Telp. (0729) 22240 website: www.stmikpringsewu.ac.id \\ E-mail: muslih.udin@ymail.com
}

\begin{abstract}
The purpose of this research is to improve learning activities using props Build Space models for the elementary school, describing the process of design of interactive multimedia on the subjects of Mathematics, knowing the results of the validation of interactive multimedia. The problem in this research is the students' grades in Maths low, conventional learning, and interactive multimedia that support the mathematics is not yet available. Development steps include: analysis, design, development, implementation, and evaluation. Subject trials, the master of the course content, instructional design experts, media expert learning, small group evaluation, individual evaluation, and field evaluation. Data collection techniques are questionnaires to data from expert reviews and test students. Data were analyzed by using a Research and Development (R \& D). The results showed the process of interactive multimedia design. The results of research that application of the model geometry aids in Mathematics Learning can increase physical activity can improve mental activity, can improve students' emotional and can improve student learning outcomes.
\end{abstract}

\begin{abstract}
Abstrak
Tujuan penelitian ini yaitu meningkatkan aktivitas belajar dengan menggunakan alat peraga model Bangun Ruang untuk Sekolah Dasar, menggambarkan proses rancang bangun multimedia interaktif pada mata pelajaran Matematika, mengetahui hasil validasi multimedia interaktif. Masalah dalam penelitian ini adalah nilai siswa dalam pelajaran Matematika rendah, pembelajaran bersifat konvensional, dan multimedia interaktif yang mendukung pada mata pelajaran Matematika belum tersedia. Langkah-langkah pengembangan meliputi: analisis, perancangan, pengembangan, penerapan, dan evaluasi. Subjek uji coba, yaitu ahli isi mata pelajaran, ahli desain pembelajaran, ahli media pembelajaran, evaluasi kelompok kecil, evaluasi perorangan, dan evaluasi lapangan. Teknik pengumpulan data yaitu kuesioner untuk data hasil review ahli dan uji coba siswa. Data dianalisis dengan teknik Research and Development (R \& D). Hasil penelitian menunjukkan proses rancang bangun multimedia interaktif. Hasil penelitian yaitu penerapan alat peraga model bangun ruang dalam Pembelajaran Matematika dapat meningkatkan aktivitas fisik, dapat meningkatkan aktivitas mental, dapat meningkatkan emosional siswa dan dapat meningkatkan hasil belajar siswa.
\end{abstract}

Kata Kunci: Aktivitas, Matematik, Alat peraga model, Multimedia Interaktif. 


\section{A. PENDAHULUAN}

Setiap siswa yang menuntut ilmu sudah pasti mengikuti kurikulum yang diberikan pemerintah di setiap sekolahnya masing-masing. Seperti halnya pelajaran matematika yang dianggap kebanyakan siswa pelajaran yang sulit salah satunya yaitu materi bangun ruang. Alasan yang timbul bermacam-macam mulai dari banyaknya rumus, hitungan yang rumit serta materi yang susah dimengerti dan dipahami.

Sebagai orang tua tentunya ingin menjadikan anaknya berhasil dalam memahami di setiap pelajaran termasuk matematika, sehingga tidak sedikit orang tua yang memberikan tambahan ilmu berupa les di luar kegiatan belajar di sekolah. Tetapi setelah les dilakukan masih saja menjadi kendala bagi siswa dalam memahami pelajaran matematika. Hal ini yang menjadikan nilai pelajaran matematika kurang memuaskan, salah satu contohnya materi bangun ruang. Bangun ruang disebut juga dengan bangun tiga dimensi yang memiliki ruang dan dibatasi oleh sisi. Bangun ruang terdiri dari kubus, balok, prisma segitiga, limas segiempat, tabung, kerucut dan bola. Dimana setiap bangun ruang tersebut memiliki rumus yang berbeda untuk luas permukaan dan volumenya.

Metode pembelajaran sendiri adalah rangkaian kesatuan antara pendekatan, strategi, taktik atau metode dalam pembelajaran. Model pembelajaran anak SD juga bisa dikatakan sebagai desain yang menggambarkan proses rincian dan penciptaan lingkungan belajar yang kondusif sehingga memungkinkan siswa untuk bisa berinteraksi dengan aktif yang akan membuat mereka mengalami pengembangan diri. Metode Collaborative Learning sering juga disebut belajar kolaboratif. Metode Collaborative Learning adalah kegiatan kelompok yang bekerja sama untuk memecahkan suatu masalah secara bersama untuk menempuh satu tujuan.

Saat ini proses pembelajaran Bangun Ruang untuk di sekolah dasar masih menggunakan cara pengajaran manual yang kurang efektif dan memakai banyak waktu untuk menyampaikan materi kepada siswa, sering dijumpai terkadang materi yang harus disampaikan kepada siswa tidak mencapai target selesai, karna kendala waktu dan kurangnya pemahaman perhitungan matematika. Oleh karena itu diperlukan suatu mekanisme baru untuk pembelajaran bangun ruang untuk sekolah dasar. Tulisan ini akan membahas sebuah sistem aplikasi yang berbasis pemrograman visual basic yang dapat memberikan pengarahan pembelajaran bangun ruang siswa sekolah dasar, dengan harapan siswa dapat lebih memahami rumus-rumus serta contoh-contoh studi bangun ruang dengan menggunakan sarana pemrograman visual basic ini sehingga tidak banyak membuang waktu untuk materi-materi setiap harinya.

Dari masalah tersebut diperlukan sebuah media pembelajaran yang dapat membangkitkan aktivitas fisik, dapat meningkatkan aktivitas mental, dapat meningkatkan emosional siswa dan dapat meningkatkan hasil belajar siswa. Selain itu membantu siswa untuk mempelajari sebuah materi pelajaran matematika bangun ruang. Banyak media pembelajaran yang dapat digunakan oleh guru untuk mengatasi hal tersebut, Salah satunya adalah dengan aplikasi media pembelajaran multimedia interaktif. Karena melalui pembelajaran media interaktif akan digambarkan dengan jelas dalam bentuk gambar dengan teknologi komputer dengan berbagai animasi gambar yang lebih menarik, sehingga minat belajar siswa akan menjadi terbangun, namun yang terpenting adalah melalui media pembelaran multimedia interaktif siswa akan lebih mudah dalam belajar bangun ruang.

Hooper (2002) dalam Retno, dkk ( 2008) menyebutkan bahwa multimedia sebagai media presentasi berbeda dari multimedia sebagai media pembelajaran. Media presentasi tidak menuntut pengguna berinteraktivitas secara aktif di dalamnya, sekalipun ada interaktivitas maka interaktivitas tersebut adalah interaktivitas yang samar (covert). Media pembelajaran melibatkan pengguna dalam aktivitas-aktivitas yang menuntut proses mental di dalam pembelajaran. Dari perspektif ini aktivitas mental spesifik yang dibutuhkan di dalam pembelajaran dapat dibangkitkan melalui manipulasi peristiwa-peristiwa instruksional (instructional events) yang sistematis. Di sini Hooper secara tegas menyatakan peran penting suatu desain instruksional di dalam multimedia pembelajaran (educational multimedia). Dengan demikian multimedia pembelajaran adalah paket multimedia interaktif di mana di dalamnya terdapat langkah-langkah instruksional yang didisain untuk melibatkan pengguna secara aktif di dalam proses pembelajaran.

\section{B. TUJUAN PENELITIAN}

Tujuan penelitian ini yaitu meningkatkan aktivitas belajar dengan menggunakan alat peraga model Bangun Ruang untuk Sekolah Dasar, menggambarkan proses rancang bangun multimedia interaktif pada mata pelajaran Matematika, mengetahui hasil validasi multimedia interaktif. 


\section{METODE PENELITIAN}

Metode penelitian dan pengembangan atau dalam bahasa inggrisnya Research and Development adalah metode penelitian yang digunakan untuk menghasilkan produk tertentu, dan menguji keefektifan produk tersebut. Sugiyono (2011: 407).

Langkah-langkah pengembangan meliputi: analisis, perancangan, pengembangan, penerapan, dan evaluasi. Subjek uji coba, yaitu ahli isi mata pelajaran, ahli desain pembelajaran, ahli media pembelajaran, evaluasi kelompok kecil, evaluasi perorangan, dan evaluasi lapangan. Teknik pengumpulan data yaitu kuesioner untuk data hasil review ahli dan uji coba siswa. Data dianalisis dengan teknik Research and Development (R \& D).

\section{HASIL DAN PEMBAHASAN}

\section{Bangun Ruang}

Dalam buku pemecahan Masalah Matematika, Clara Ika Sari Budhayanti (2008) menerangkan bangun ruang adalah bangun yang memiliki tiga dimensi yaitu panjang, lebar, dan tinggi. Menurut GBPP 2004 materi bangun ruang disampaikan di SD pada siswa kelas IV semester II meliputi : menentukan sifat-sifat (sisi, titik sudut, dan rusuk) bangun ruang sederhana, menggambar jaringan-jaringan kubus dan balok.

Bangun ruang adalah bagian ruang yang dibatasi oleh himpunan titik-titik yang terdapat pada seluruh permukaan bangun tersebut. Permukaan bangun itu disebut sisi. Dalam memilih model untuk permukaan atau sisi, sebaiknya guru menggunakan model berongga yang tidak transparan. Model untuk bola lebih baik digunakan sebuah bola sepak dan bukan bola bekel yang pejal, sedangkan model bagi sisi balok lebih baik digunakan kotak kosong dan bukan balok kayu. Hal ini mempunyai maksud untuk menunjukkan bahwa yang dimaksud sisi bangun ruang adalah himpunan titik-titik yang terdapat pada permukaan atau yang membatasi suatu bangun ruang tersebut. Sedangkan model benda masih dipergunakan untuk mengenalkan siswa pada bangun ruang yang meliputi keruangannya secara keseluruhan.

Adapun bangun ruang yang dipelajari untuk siswa Sekolah Dasar adalah kubus, balok, tabung, kerucut, dan bola.

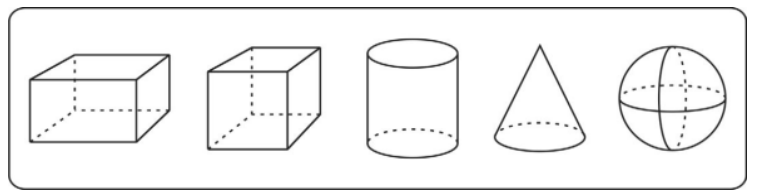

Gambar 1. Kubus, balok, tabung, kerucut, dan bola. a. Sifat-sifat Bangun Ruang

1. Kubus

Kubus adalah bangun ruang yang dibentuk oleh enam bidang sisi berbentuk persegi yang kogruen. Kubus juga disebut bidang enam beraturan atau Hexader Sumadi Menurut Heruman (2007) bangun ruang kubus merupakan bagian dari prisma yang memiliki sisi yang sama besar.

Adapun sifat-sifat kubus adalah:

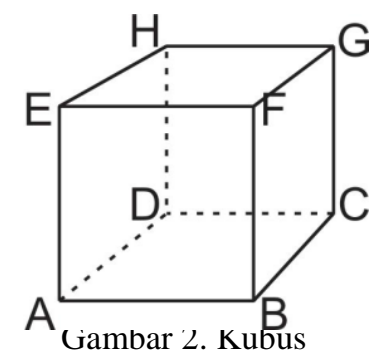

a) Sisi-sisi pada kubus ABCD EFGH adalah:

Sisis ABCD EFGH

Sisi ABFE DCGH

Sisi ADHE BCGF

Jadi, ada 6 sisi pada bangun ruang kubus.

b) Rusuk-rusuk pada kubus ABDC EFGH adalah:

Rusuk AB BC AE

Rusuk EF FG BF

Rusuk HG EH CG

Rusuk DC AD DH

Jadi ada 12 rusuk pada bangun ruang kubus.

c) Titik-titik sudut pada kubus ABCD EFGH adalah:

Titik sudut A, titik sudut E

Titik sudut $B$. titik sudut $F$

Titik sudut $\mathrm{C}$, titik sudut $\mathrm{G}$

Titik sudut $\mathrm{D}$, titik sudut $\mathrm{H}$

Jadi ada 8 titik sudut pada bangun ruang kubus.

2. Balok

Balok adalah bangun ruang yang dibentuk oleh enam bidang sisi berbentuk persegi panjang yang sisinya berhadapan kongruen, Sumadi (2008) Balok adalah bangun ruang yang dibatasi oleh tiga pasang (enam buah) pesegi panjang dimana satu pasang persegi panjang saling sejajar (berhadapan) dan ukuran sama.

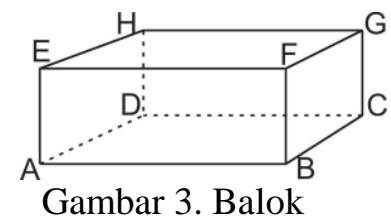

a) Sisi-sisi pada balok ABCD EFGH

Sisi ABCD EFGH

Sisi ABFE DCGH

Sisi ADHE BCGF

Jadi, ada sisi pada bangun ruang balok. 
Sisi $\mathrm{ABCD}=$ sisi EFGH

Sisi $\mathrm{BCFG}=$ sisi ADHE

Sisi $\mathrm{ABFE}=$ sisi EFGH

b) Rusuk-rusuk pada balok ABCD EFGH adalah:

Rusuk AB, BC AE

Rusuk EF, FG, BF

Rusuk HG, EH, CG

Rusuk DC, AD, DH

Jadi, ada 12 rusuk pada bangun ruang balok.

Rusuk $\mathrm{AB}=\mathrm{EF}=\mathrm{HG}=\mathrm{DC}$

Rusuk $\mathrm{BC}=\mathrm{FG}=\mathrm{EH}=\mathrm{AD}$

Rusuk $\mathrm{AE}=\mathrm{BF}=\mathrm{CG}=\mathrm{DH}$

c) Titik-titik sudut pada balok ABCD EFGH adalah:

Titik sudut $\mathrm{A}, \mathrm{E}$

Titik sudut $\mathrm{B}, \mathrm{F}$

Titik sudut $\mathrm{C}, \mathrm{G}$

Titik sudut D, H

3. Tabung, Kerucut, dan Bola

Bangun ruang tabung, kerucut, dan bola berbeda dengan kubus dan balok karena dalam bangun ruang ini terdapat sisi lengkung.
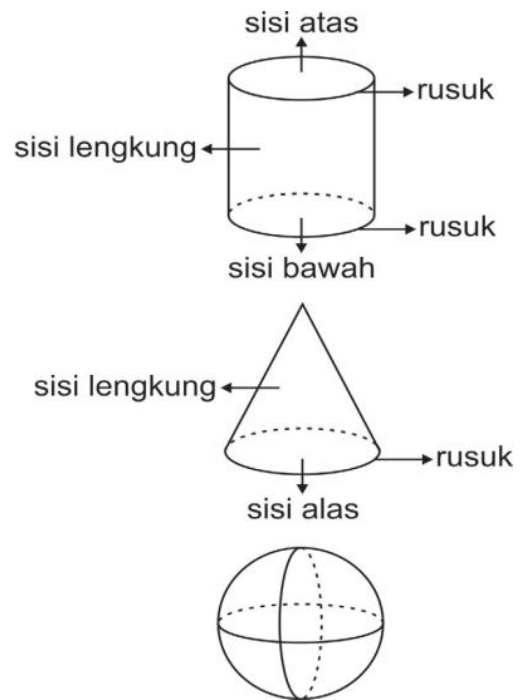

Gambar 4. Tabung, Kerucut, dan Bola

Bangun ruang tabung mempunyai 3 buah sisi, yaitu sisi lengkung, sisi atas, dan sisi bawah. Tabung mempunyai 2 buah rusuk, tetapi tidak mempunyai titik sudut. Bangun ruang kerucut mempunyai dua buah sisi, yaitu sisi alas dan sisi lengkung. Kerucut hanya mempunyai sebuah rusuk dan sebuah titik sudut yang bias disebut titik puncak. Yang terahir, bangun ruang bola hanya memiliki sebuah sisi lengkung yang menutupi seluruh bagian ruangnya.

b. Jaring-jaring kubus dan balok

Bangun ruang kubus dan balok terbentuk dari bangun datar persegi dan persegi panjang.
Gabungan dari beberapa persegi yang membentuk kubus disebut jarring-jaring kiubus. Sedangkan jarring-jaring ballok adalah gabungan dari beberapa persegi panjang yang membentuk balok Burham Mustaqim dan Ary Astity (2010)
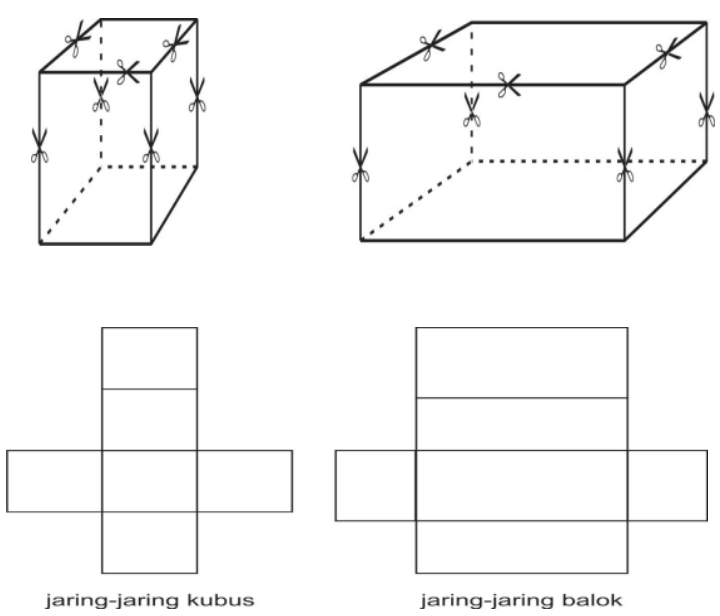

Gambar 5. Jaring-jaring kubus dan balok

\section{Sekolah Dasar (SD)}

Sekolah Dasar (SD) merupakan sebuah lembaga pendidikan dari pemerintah yang mewajibkan anak-anak lanjutan dari pendidikan anak usia dini ke sekolah dasar ini, dan merupakan jenjang yang paling mendasar dalam dunia pendidikan setelah pendidikan anak usia dini (PAUD) yang ditempuh selama 6 tahun dari mulai kelas 1 SD sampai kelas 6 dengan ketentuan syarat lulus nanti setelah kelas 6 harus mengikuti dahulu yang dinamakan ujian nasional atau ujian sekolah. Pengertian pendidikan yang sangat umum dikemukakan oleh Driyakara (1980) yang menyatakan bahwa pendidikan adalah upaya memanusiakan manusia muda.

Di dalam Undang-undang republik Indonesia Nomor 2 Tahun 1989 tentang Sistem Pendidikan Nasional Pasal 1 ayat 1 dinyatakan bahwa "Pendidikan adalah Usaha sadar untuk menyiapkan peserta didik melalui kegiatan bombing, pengajar, dan atau latihan bagi peranannya di masa yang akan datang”.

Acuan Tujuan pendidikan SD harus mengacu kepada tujuan pendidikan nasional dan tujuan pendidikan dasar pendidikan dasar serta memperhatikan tahap karakteristik perkembangan siswa, kesesuaian dengan lingkungan dan kebutuhan pembangunan daerah, arah pembangunan nasional, serta memperhatikan perkembangan ilmu pengetahuan dan teknologi dan kehidupan umat manusi secara global. 
Tujuan pendidikan SD sebagaimana ditetapkan dalam pasal 13 Undang-undang Nomor 2 tahun 1989 bahwa pendidikan Dasar diselenggarakan untuk mengembangkan sikap dan kemampuan serta memberikan pengetahuan dan keterampilan dasar yang diperlukan untuk hidup da dalam masyarakat serta mempersiapkan peserta didik yang memenuhi persyaratan untuk mengikuti pendidikan menengah. Tujuan pendidikan sekolah dasar dapat diuraikan secara terperinci, seperti berikut :

a. Memberikan bekal kemampuan membaca, menulis, dan berhitung

b. Memberikan pengetahuan dan keterampilan dasar yang bermanfaat bagi siwa sesuai dengan tingkat perkembangannya

c. Mempersiapkan siswa untuk mengikuti pendidikan di SLTP.

\section{Visual Basic}

Menurut Subari dan Yuswanto (2008) dalam bukunya Panduan Lengkap Pemograman Visual Basic 6.0, beliau menerangkan bahwa Microsoft Visual Basic yaitu aplikasi yang dijalankan dengan menggunakan system operasi windows yang juga merupakan hasil karya dari perusahaan Microsoft corporation. Aplikasi Visual Basic memiliki keunggulan antara lain visual basic memiliki kemampuan untuk mengkompilasi dan menjalankan program, sehingga menjadi visual basic memiliki kemudahan dan kecepatan di dalam mengakses program.

\section{Perencanaan Dan Implementasi}

Perencanaan adalah suatu proses dan cara berfikir yang dapat membantu menciptakan hasil yang diharapkan. Perencanaan yang dibuat merupakan antisipasi dan perkiraan terhadap proses yang akan dilakukan dalam pembelajaran, sehingga tercipta situasi yang memungkinkan terjadinya proses belajar sesuai dengan tujuan yang diharapkan. Adapun rancangan penelitian ini diimplementasikan melalui tahapan-tahapan sebagai berikut:

\section{a. Perencanaan}

Dalam tahap perencanaan peneliti membuat rencana pelaksanaan pembelajaran (RPP), membuat soal-soal dan menyiapkan media pembelajaran.

b. Tindakan

Dalam penelitian ini melaksanakan penelitian kolaboratif, jadi guru kelas yang bertugas untuk mengajar sesuai RPP yang dibuat peneliti menggunakan model pembelajaran kontekstual.

\section{c. Pengamatan}

Peneliti melakukan observasi atau pengamatan selama proses pembelajaran berlangsung. Hal-hal yang diamati antara lain keaktifan siswa, cara mengajar guru dalam menerapkan model pembelajaran kontekstual, dan sejauh mana model pembelajaran kontektual dapat meningkatkan proses pembelajaran.

d. Refleksi

Penelitian melakukan refleksi terhadap hasil yang didapat dalam setiap siklus apakah telah berhasil atau belum dengan melihat hasil evaluasi siswa.

\section{Diagram Conteks}

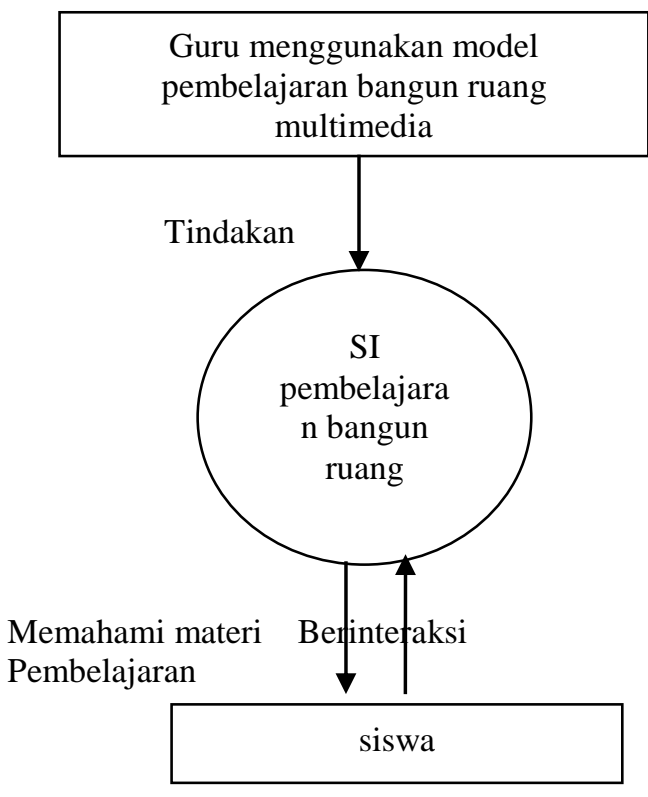

Gambar 6. Diagram Conteks

\section{DFD (Data Flow Diagram)}

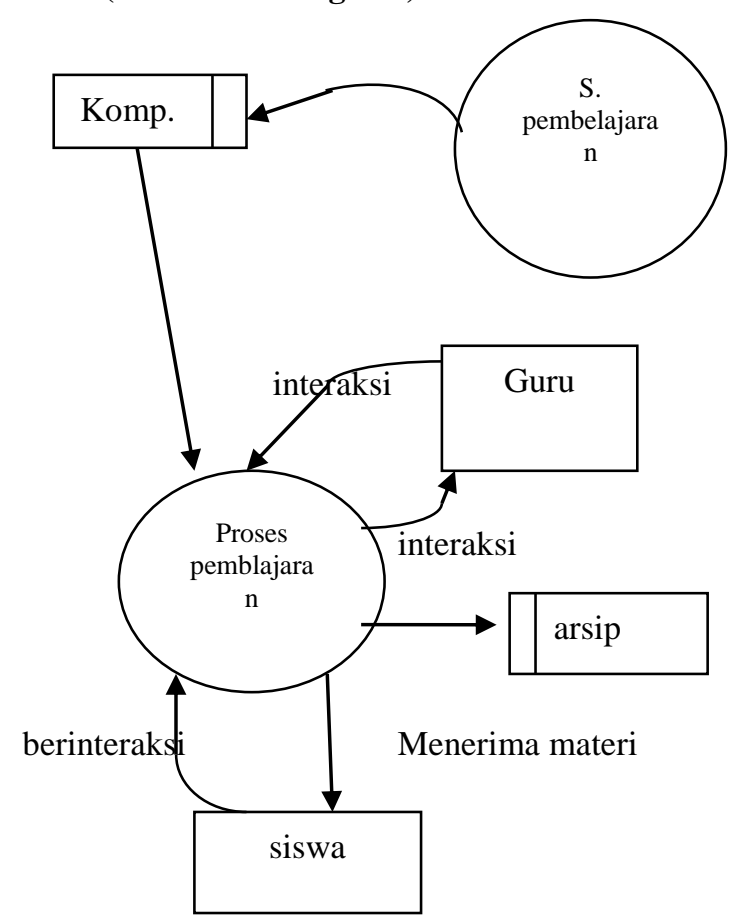

Gambar 7. DFD (Data Flow Diagram) 


\section{Implementasi Sistem}

1. Aplikasi pada Visual Basic 6.0

Aplikasi ini di terapkan pada pembelajaran bangun ruang disekolah dasar dengan dukungan bahasa pemrograman Visual Basic 6.0.

\section{a. Antar muka system}

Aplikasi pembelajaran bangun ruang mempunyai halaman utama yang berisikan tombol mulai yang digunakan untuk masuk kedalam aplikasi system dan tombol keluar digunakan untuk keluar dari aplikasi system.

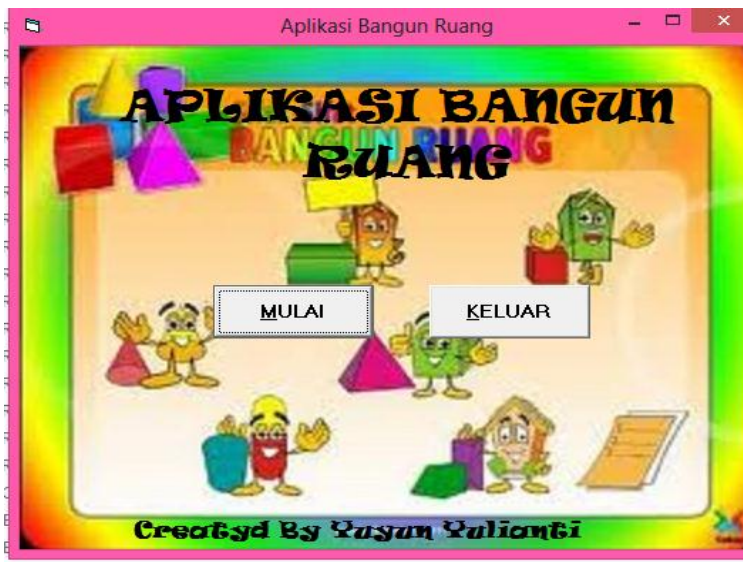

Gambar 8. Tampilan halaman muka

b. Antar muka form menu pilihan Antar muka menu pilihan memuat menu daftar bangun ruang yang dapat digunakan untuk memilih aplikasi bangun ruang mana yang akan digunakan untuk pemrosesan Kubus, Kerucut, Balok, Tabung, Prisma, Bola dan Limas.

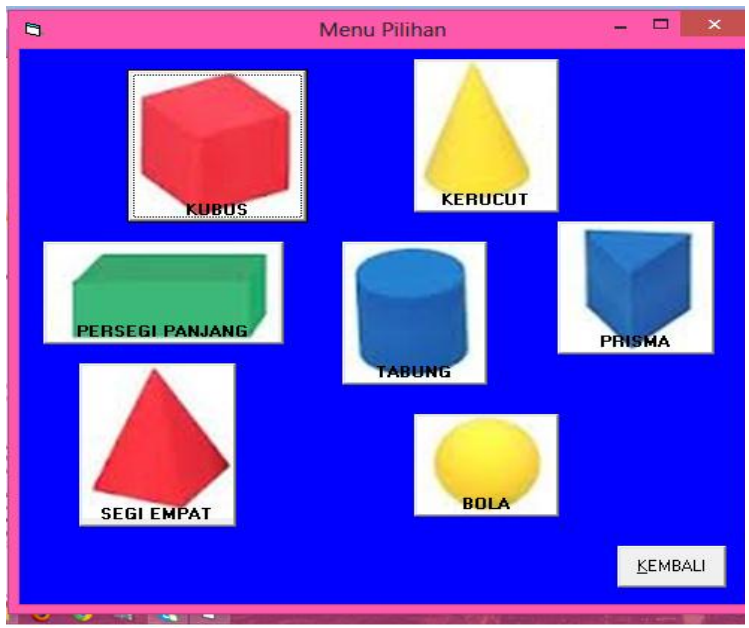

Gambar 9. Tampilan halaman menu pilihan bangun ruang.

c. Tampilan Bangun Ruang Kubus

Antar muka ini berisi pemrosesan bangun ruang kubus meliputi volume kubus yang memiliki Rumus Volume $=\mathrm{SxSxS}$.

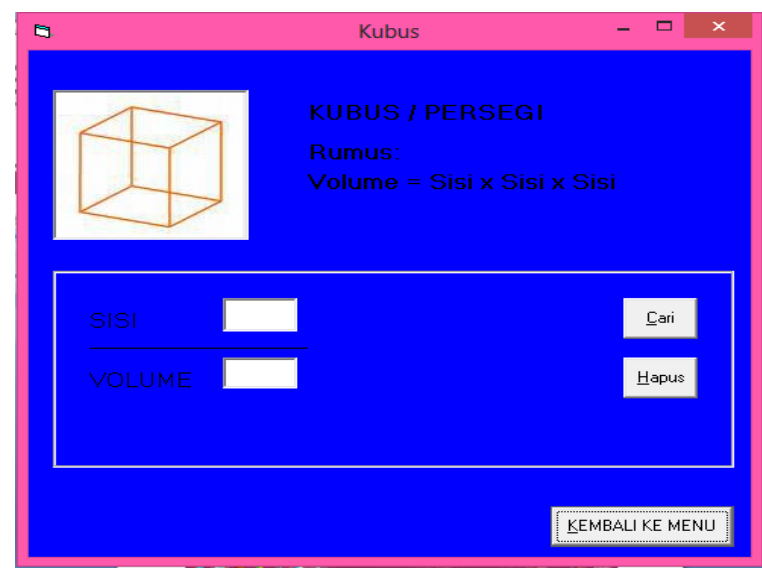

Gambar 10. Tampilan antar muka kubus

\section{d. Tampilan Bangun Ruang Balok}

Antar muka ini digunakan untuk bangun ruang balok yang meliputi panjang, lebar, tinggi sebagai rumus dalam penghitungan Volume Balok.

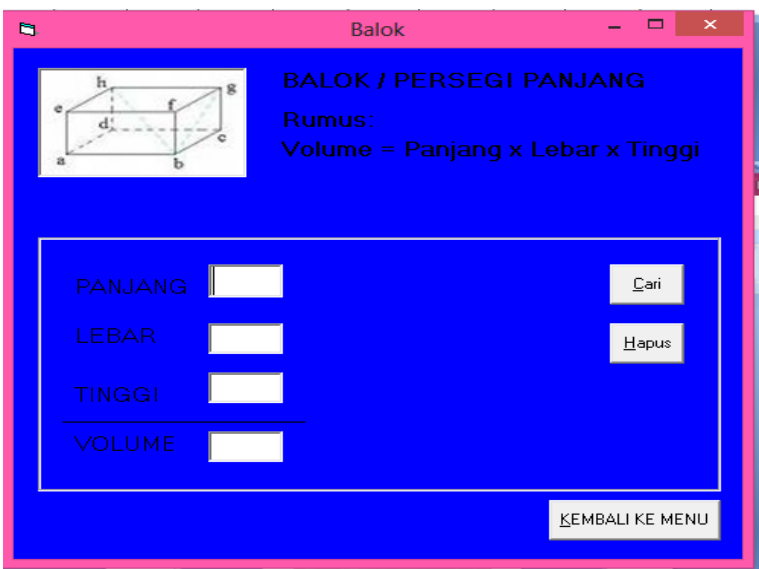

Gambar 11. Tampilan antarmuka balok

\section{e. Tampilan Bangun Ruang kerucut}

Antar muka ini berisi tampilan bangun ruang kerucut yang digunakan untuk pemrosesan Volum dengan rumus Phi x jarijari $\mathrm{x} 1 / 3$ dan Rumus Luas $=($ Phi $\mathrm{x}$ jari-jari $) \mathrm{x}$ (sisi $\mathrm{x}$ jari-jari).

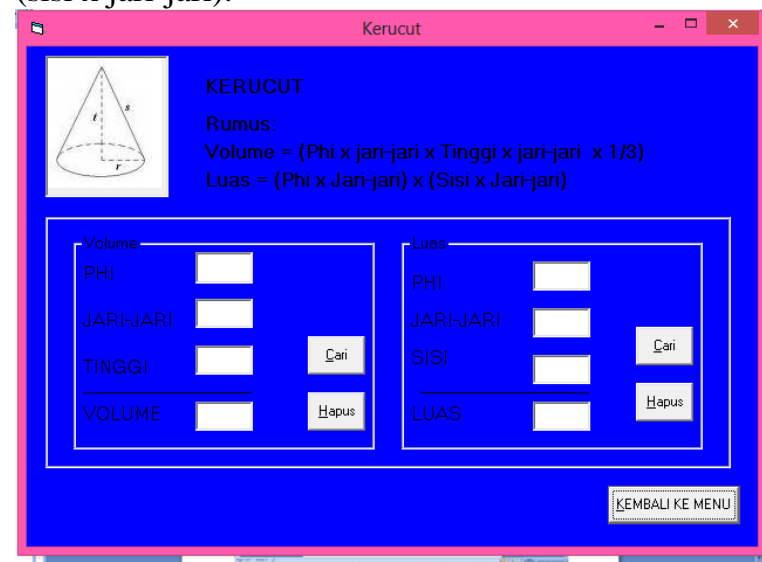

Gambar 12. Tampilan antarmuka kerucut. 


\section{f. Tampilan Bangun Ruang Tabung}

Antarmuka ini berisi tampilan bangun

ruang tabung yang digunakan untuk pemrosesan peng hitungan volume dengan rumus Volume $=$ Phi $\mathrm{x}$ jari-jari $\mathrm{x}$ tinggi dan rumus Luas $=($ Phi $\mathrm{x}$ jari-jari $\mathrm{x} 2) \mathrm{x}($ tinggi $\mathrm{x}$ jari-jari) .

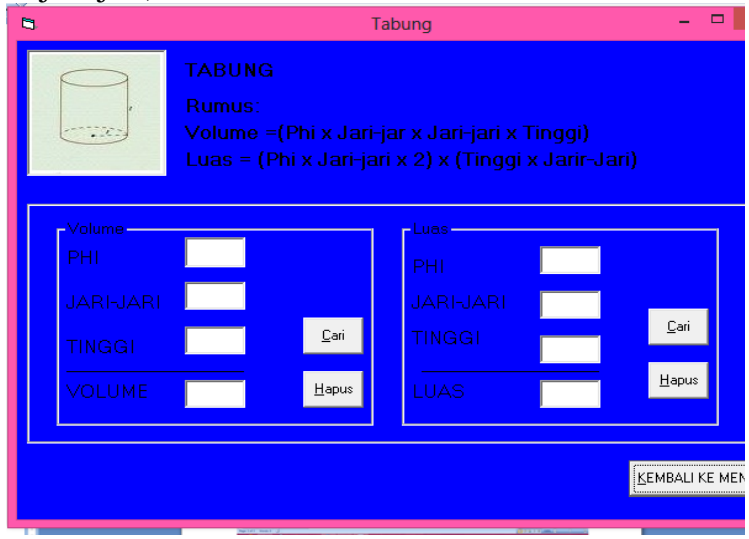

Gambar 13. Tampilan antarmuka tabung

\section{g. Tampilan Bangun Ruang Prisma}

Antar muka ini berisi tampilan bangun ruang kerucut yang digunakan untuk pemrosesan penghitungan volume dengan rumuas Volume $=($ Alas Segi Tiga $\mathrm{x}$ Tinggi Segitiga $\mathrm{x}$ Tinggi Prisma /2)

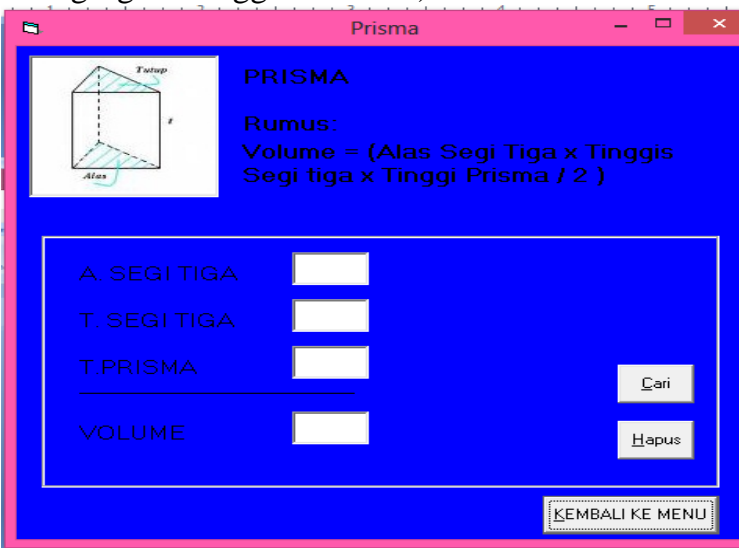

Gambar 14. Tampilan antarmuka tabung

\section{h. Tampilan Bangun Ruang Limas Segi Empat}

Antar muka ini berisi tampilan bangun ruang limas segi empat yang digunakan untuk pemrosesan volum dan luas dengan rumus Volume $=$ Panjang $\mathrm{x}$ Lebar $\mathrm{x}$ Tinggi $/ 3$ dan rumus Luas $=(($ Panjang $\mathrm{x}$ Luas $) \times$ Tinggi $)+$ (Panjang x Luas)

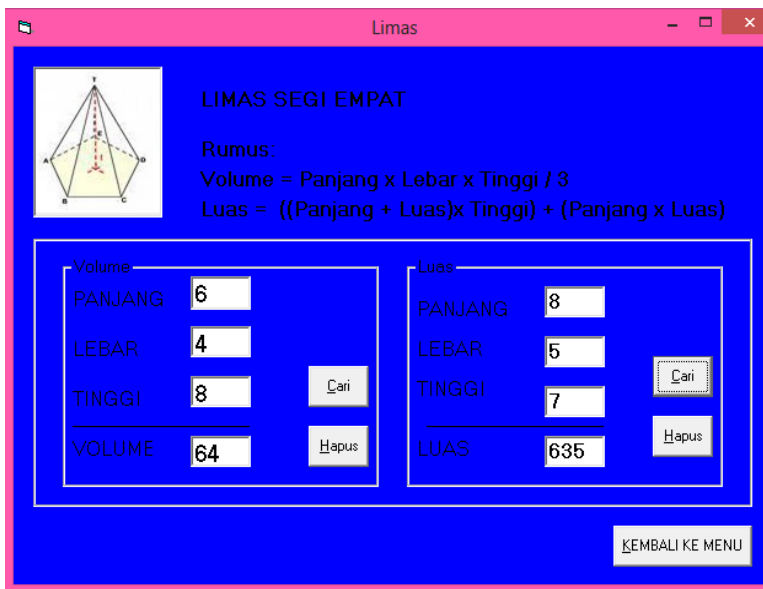

Gambar 15. Tampilan antarmuka limas segi empat

\section{i. Tampilan Bangun Ruang Bola}

Antarmuka ini digunakan untuk bangun ruang balok yang meliputi Perhitungan Volume bola dan Luas Bola dengan Rumus Volume $=(($ Phi $\mathrm{x}$ jari-jari $\mathrm{x}$ tinggi $\mathrm{x}$ tinggi $\mathrm{x}$ tinggi) $\mathrm{x} 4 / 3$ ) dan Rumus Luas $=($ Phi $\times$ jari-jari $\times$ jari-jari $) \times 4)$.

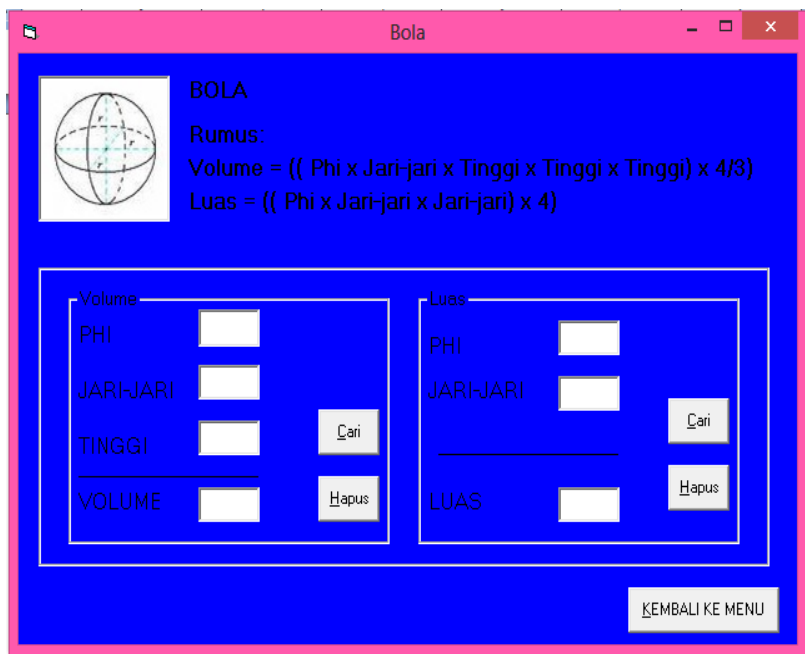

Gambar 16. Tampilan antarmuka limas bola 


\section{E. PENUTUP}

\section{1) KESIMPULAN}

Simpulan yang dapat diambil dari penelitian ini adalah sebagai berikut :

1. Pengguna (penerapan) pembelajaran bangun ruang kemampuan menghitung dalam pembelajaran Matematika ternyata dapat meningkatkan kemampuan menghitung siswa. Hal ini terindikasi dari adanya peningkatan perolehan kemampuan kepahaman menghitung yang rendah meningkat ke kemampuan kepahaman menghitung yang lebih tinggi.

2. Pelaksanaan pembelajaran bangun ruang Matematika berjalan efektif dalam menerapkan pembelajaran multimedia interaktif dapat mensinergikan antara kemampuan fisik dan emosional siswa sehingga kemampuan menghitungnya meningkat.

\section{2) Saran}

Adapun saran yang dapat diberikan sehubungan dengan pelaksanaan penelitian ini adalah :

1. Aplikasi dapat dikembangkan lagi dengan menambahkan materi lainnya, bukan hanya bangun ruang saja melainkan materi lainnya sehingga siswa juga lebih aktif lagi mengusai matematika.

2. Aplikasi ini lebih banyak lagi di tambahkan contoh-contoh studi lagi, agar siswa lebih paham lagi.

3. Aplikasi ini perlu dikembangkan dengan adanya menu-menu kategori materi apa saja yang akan dicari agar pengguna tidak bingung untuk menggunakannya.

\section{DAFTAR PUSTAKA}

Clara Ika Sari Budhayanti, dkk. 2008. Pemecahan Masalah Matematika. Jakarta: Departmen Pendidikan nasional

Gatot Muhsetyo. 2008. Pembelajaran Matematika SD. Jakarata: Universitas Terbuka.

Hadibin, Mochamad Miswar dkk. 2012. Pembangunan Media Pembelajaran Teknik Komputer Jaringan Kelas X Semster Ganjil Pada Sekolah Menengah Kejuruan Taruna Bangsa Pati Berbasis Multimedia Intera Ktif. IJCSS. UNSA

Heruman. 2007. Model Pembelajaran Matematika Di SD. Bandung: PT Remaja Rosdakarya.

Retno, Margono, Bambang Eka Purnama, Study Of Interaktif Recognition Letter and Number For Children With Computer Multimedia, Indonesian Jurnal on Computer Scoence - Speed (IJCSS) 4 Volume 3 Nomor 1 Agustus 2008, ISSN $1979-9330$

Rini, Handayani, Analisis Faktor-faktor yang Menentukan Efektivitas Sistem Informasi pada Organisasi Sektor Publik, penerbit Rini Handayani, 2010.

Santika, Adi, Wira, I Made, dkk, Layanan Informasi Untuk Pasien Rumah Sakit Menggunakan SMS, penerbit Iwan Binanto, 2010

Suharjana, Agus. 2008. Mengenal Bangun Ruang dan Sifat-Sifatnya di Sekolah Dasar. Pusat Pengembangan dan Pemberdayaan Pendidik dan Tenaga Kependidikan Matematika. Jakarta

Subari dan Yuswanto. 2008. Panduan Lengkap Pemograman Visual Basic 6.0. Cerdas Pustaka Publizer. Jakarta.

Undang-undang RI. Nomor 2 Tahun 1989 tentang Sistem Pendidikan Nasional Pasal 1 ayat 1 